\title{
Muslim-Friendly Railway Services: Concept and Challenges of Malaysian Electric Train Service (ETS)
}

\author{
Siti Norhamimah Abdul Halim ${ }^{1 *}$, Ahmad Aiman Harum ${ }^{1}$, Mohammad Aizat Jamaludin ${ }^{1}$, Betania Kartika \\ Muflih $^{1}$ \\ ${ }^{1}$ International Institute for Halal Research and Training (INHART), Level 3, KICT Building, International \\ Islamic University Malaysia (IIUM), 53100 Jalan Gombak, Selangor, Malaysia \\ *Corresponding author: Siti Norhamimah Abdul Halim, International Institute for Halal Research and Training \\ (INHART), Level 3, KICT Building, International Islamic University Malaysia (IIUM), 53100 Jalan Gombak, \\ Selangor, Malaysia.; hamimah.abdulhalim@gmail.com
}

\begin{abstract}
Muslim-Friendly Railway Services (MFRS) is a service that accommodates Muslims' needs during travel. There are two basic needs of Muslims during travel, which are halal food and place for prayers. Therefore, it is important for MFRS to fulfil these two requirements. Besides halal food, beverage and Muslim prayer facility (musolla), other elements that can be included in MFRS are prayer time, Ka'abah direction (qiblah), ablution capability (wudhu'), availability of prayer rug or mat, female prayer apparel, a copy of the Al-Quran, supplication guide $\left(d u^{\prime} a\right)$, segregation of gender and appropriate entertainment are discussed below. Qualitative research has been used in this study, consisting of data obtained through library research and semi-structured interviews. This paper attempts to study the concept of implementing MFRS in the Electric Train Service (ETS) by Malaysian Railways (KTMB). This study also deliberates on the challenges faced by ETS operation upon implementing the MFRS which are high cost for implementation, negative perception among non-Muslim passengers and the acceptance and implementation of the MFRS in Malaysia might be complicated. This study found that more awareness and knowledge on the MFRS should be increased and disseminated among ETS consumers and railway industry players to enhance transportation services according to Shariah principles. Perhaps this study could help to develop tourism sector in Malaysia thus increase the country's income by attracting many tourists from outside and open many job opportunities.
\end{abstract}

Keywords: Muslim-friendly tourism; Muslim travel; transport; halal industry services; railway

Received: $14^{\text {th }}$ May 2020

Citation: Abdul Halim SN, Harum AA, Jamaluddin MA, et al. Muslim-friendly railway services:

Accepted: $16^{\text {th }}$ June 2020 Concept and challenges of Malaysian electric train service (ETS). J Halal Ind Serv 2020; 3(1):

Published Online: $22^{\text {nd }}$ June 2020 a0000094. https://doi.org/10.36877/jhis.a0000094

\section{Introduction}

Halal denotes permissibility in Islam, whereby no restriction exists, as it is allowed by the ultimate lawmaker, Allah the Almighty (Al-Qaradhawi, 2015). However, halal does not only apply to food and beverage, but also to non-food items such as pharmaceuticals, cosmetics, financing, management, logistics, and tourism (Abdullah \& Mustafa, 2018). The demand of halal products and services in Malaysia is increasing due to the awareness of the 
benefits of halal products and services among Muslims as well as non-Muslims (Razak, Alias \& Samad, 2015). Malaysia, also as an Islamic developing country, should consider other aspects in order to develop halal industry, which is transportation services. It is significant in playing the role to fulfil Muslim needs as well as inspire people to live more comfortably. Unfortunately, there is still lack of resources and initiatives in providing musolla or prayer places for Muslim passengers and tourists (Hamid et al., 2015).

Recently, there was an issue on social media where some Muslim passengers performed Fajr prayer in an open space on a train since the time for Fajr is earlier than the previously scheduled (Azza, 2019). This issue attracted many Malaysian citizens, especially Muslims, to realise the need for prayer facilities on trains. Basically, a trip by train, especially on the Electric Train Service (ETS) takes a long time, usually more than 2 hours, depending on the destination. Performing prayers is compulsory for all Muslims, which must be completed immediately upon each prayer time. Thus, Muslim passengers who use ETS for their transportation also need to perform their duty (Md Sham, Hj Tibek \& Jurami, 2015). Therefore, it is crucial to provide musolla on ETS to accommodate Muslims' needs during travel.

Since the establishment of the ETS in 2010, there had been no musolla available, but it was then provided by KTMB after receiving several demands from Muslim passengers. Besides, according to SPAD, the number of passengers has been increasing, showing that ETS is a preferable public transport in Malaysia (Selamat \& Zolkiply, 2017). However, there is a lack of study in identifying the feasibility of implementing the musolla on trains based on MFRS requirements.

\section{Concept of Muslim-Friendly Railway Services (MFRS) in ETS}

Travel is significant to everyone; and Islam acknowledges the need to travel. The main purpose for travelling in Islam is to inculcate the awareness of being a humble servant to Allah the Almighty (Salleh, Nor \& Azmin, 2019). The al-Quran states:

"It is He who made the earth tame for you so walk among its slopes and eat of His provision-and to Him is the resurrection." (al-Quran 67:15)

Nowadays, people travel for many purposes such as for work, worship, business, medical treatment, education, or leisure (Zawawi \& Ramli, 2016). Travel is synonymous with transportation because people need the means to move from one place to another. Today, people can choose any kind of travelling modes either by land, water, and air.

The concept of Muslim-friendly travel is preferred in this study. Based on the literature review and interviews with some interviewees, Muslim-friendly service seems to be more suitable because its nature applies to both Muslims and non-Muslims alike. Generally, this mode is more relaxed, friendly, and acceptable to the industry and service providers, who may or may not be Muslims (Zawawi \& Ramli, 2017). In addition, the need for Muslimfriendly requirements is less strict in certain areas compared to Shariah-Compliant Services that need to cover other aspects which include management, finance, and other related components. Shariah-Compliance Services (SCS) usually cover the whole operation including financial transactions, which are based on Shariah principles. It is not only limited to serving halal food and beverage but, also includes the requirements for health, safety, 
environment, and impacts on the economic aspects of all people, despite race, faith or culture (Ahmat et al., 2015).

Muslim-friendly service refers to the availability of facilities and services that cater to Muslims' needs specifically (Jais, 2017). Muslims have specific needs to be fulfilled in terms of religious obligations (ibadah). According to Battour (2018), Muslim-friendly in the context of the tourism industry is defined as an attempt to make tourism experience enjoyable to observant Muslims. Besides, MS2610:2015 stated that Muslim-friendly hospitality services are products or services in the travel and tourism industry guided by Shariah requirements that cater to or provide facilities suitable for Muslim travelers.

Therefore, Muslim-Friendly Railway Services (MFRS) is a railway service that accommodates Muslims' needs during travel. There are two basic needs of Muslims during travel, which are halal food and prayer services. Providing halal food will give satisfaction and loyalty among Muslims because the process meets Shariah rules (Shakona et al., 2015). Battour, Ismail and Battor (2011) also stressed that prayer rooms and halal food availability are considered as the most crucial facilities for Muslims. These needs are to ensure that Muslim passengers' religious obligations can be observed during travel. Besides, the material needs that include food, facilities, and equipment are most important for transport passengers (Peng, Song \& Yang, 2017). Therefore, it is important for the MFRS to provide such a service that fulfils these two needs. In addition, other elements can also be included with more details in other sections of the MFRS to provide convenience to Muslims to perform their religious duties anywhere without any excuse. These elements include prayer time notification or schedule, qiblah direction, ablution capability, availability of prayer rugs or mats, female prayer apparel, copy of the Al-Quran and supplication guide $\left(d u^{\prime} a\right)$, gender segregation and appropriate entertainment.

\section{Materials and Methods}

This research applied a qualitative approach in studying the concept of the MFRS. Data were obtained through library research from journals, books, conference and seminar papers, internet resources and official reports related to the field of study. Besides, the primary source of this study was obtained from semi-structured interviews. Several questions were constructed as a guideline to collect data from interview sessions with the interviewees. The duration of each interview session was approximately 45 minutes to one hour and was recorded. The interviews were then transcribed, so that the main points from the verbal text could be determined and classified into themes. After the process, the result was translated into English. Finally, the data were analysed by comparing the themes with the research questions.

\section{Results}

\section{Elements in Muslim-Friendly Railway Services}

\section{Halal Food and Beverage}

Providing halal food and beverage is a vital element in the MFRS. Halal food and beverage do not only suit Muslims but also non-Muslims because it is believed to be able to provide good quality, integrity, hygiene and safety (Baharuddin et al., 2015). One of the facilities on-board the ETS is the F\&B Bistro. The bistro has already been certified halal by 
JAKIM, allowing KTMB to become the first halal-certified F\&B train service in the world (Arbee, 2015).

The standard that needs to be applied in order to be certified halal is MS1500:2019 Halal Food-General Requirement, which is a standard specifically developed to ensure only halal food is produced and served. Therefore, the ETS complied with the requirements stipulated in the document for the production, preparation, handling, and storage of halal food and shall continue to be verified from time to time through site inspections as deemed necessary by the relevant authority (Jais, 2019).

In addition, Quantaniah, Noreina \& Syakinah (2013) stated that halal certification is not only an examination of food processing in its preparation, slaughtering, cleaning, processing, handling, disinfecting, storing, transporting, and managing practices but, it also covers all aspects in the food supply chain, as well as personal hygiene, clothing, utensils, and working area. By adhering to all the requirements, halal certification can enhance the level of integrity and satisfaction among ETS users.

\section{Musolla}

According to Bahardeen (2014), Muslim travellers need to have food services and prayer facilities for performing prayers (solah) in many common tourist attractions such as shopping malls, theme parks, hotels and other tourist sites. Obtaining halal food and performing 5-time prayers a day are compulsory for all Muslims throughout the world (Kamarudin \& Ismail, 2016). Allah the Almighty said:

"And be steadfast in prayer, practice regular charity, and bow down (in worship)" (al-Quran 2:43)

Therefore, as a common tourist-attractive mode of transportation, the ETS needs to provide musolla in order to facilitate Muslim travelers or passengers in performing their religious duty. Kamarudin and Ismail (2016) mentioned that in terms of performing prayers, the government should provide good facilities as to ensure the comfort of Muslim travelers to stay longer with the ability to maintain a good quality of their prayers.

According to the Mufti of Wilayah Persekutuan, Dato Seri Dr Zulkifli Mohamad alBakri, Muslims are allowed to perform prayers on the ETS since a trip takes a long time over a great distance and passengers do not have the opportunity to stop for the purpose of performing prayers until they have reached their destination (Rusli, 2018). Muslims are also allowed to perform jama' (combined) and qasr (shortened) prayers during travel as to ease them (Yunus, 2005). In Islamic teaching, these called allowances or rukhsah during a Muslim's travel to shorten and combine the prayers (Hariani, Rahmanita \& Ingkadijaya, 2017). This reason is to ensure that Muslims can fulfil their obligations and seek blessing from Allah the Almighty during the travel.

Travelling is one excuse for a Muslim to shorten one's prayer of four rak'ahs (unit of prayer) to only two rak'ahs, as stated in the al-Quran, Sunnah, and consensus of Muslim scholars (ijma) (Musharraf, 2016). As mentioned in the al-Quran, Allah the Almighty said: 
"And when you travel throughout the land, there is no blame upon you for the shortening of prayer....” (al-Quran 4:101)

Moreover, it is permissible for a traveler to combine the Zuhr (noon) prayer and the 'Asr (Afternoon) prayer at either due time, and/or combine the Maghrib (sunset) prayer and the Isha (night) prayer at either due time. Based on the researchers' observation, KTMB has already provided the musolla on the ETS to provide space for Muslim passengers to perform prayers, but unfortunately, the space is narrow and is not segregated between men and women, as shown in Figure 1 below.

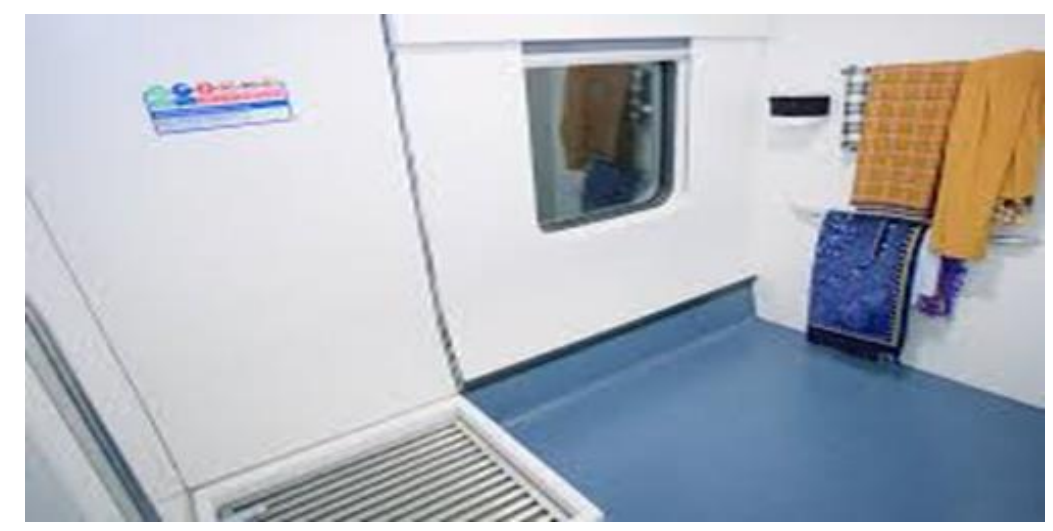

Figure 1. The musolla and place of ablution in ETS located in one space for men and women. Source: Official web site of KTMB (retrieved from https://www.ktmb.com.my/OnboardKomuter.html)

Based on MS2610:2015 (5.2.3 Public Musolla), one of the requirements for the implementation of a Muslim-friendly policy is the segregation between men and women in the service provided (Department of Standards Malaysia, n.d.). Mokhtar (2011) stated that it is preferable for males and females to be given segregated spaces or access for prayer. Therefore, the MFRS is established to provide this facility for Muslims to perform their obligations in a comfortable environment with appropriate facilities while safeguarding their religious requirements (Hariani, Rahmanita \& Ingkadijaya, 2017).

\section{Prayer Time}

The MFRS should provide information on prayer times. It is difficult for Muslim passengers to perform prayers without knowing the exact time. Information on an imminent prayer time is an approach to assist Muslim passengers to perform prayers at a fixed time (Saffinee, 2017). With this in mind, prayer time information is also considered as prayer facilities (Hashim, Murphy \& Hashim, 2007). Thus, on the ETS, a specific time for prayer can be announced or shown on LCD monitors that should be provided. 


\section{Qiblah}

Facing the qiblah during prayers is one of the compulsory requirements to perform a prayer (Mokhtar, 2009). Muslims around the world should face the Ka'abah during their daily prayers. As mentioned by Tarabishy (n.d.), facing the qiblah i.e. directly toward the Ka'abah in Makkah is highly crucial for performing a complete prayer (solah). Muslims have been ordered specifically to turn towards the sacred mosque. As mentioned in the al-Quran, Allah the Almighty stated as below:

"And from wherever you go out for prayer, turn your face toward al-Masjidil al-Haram. And wherever you believer may be, turn your faces toward it, in order that the people will not have any argument against you, except for those of them who commit wrong: so, fear them not but fear Me. And (it is) so I may complete my favour upon you and that you may be guided." (al-Quran 2:50)

The qiblah on the ETS might change regularly based on the train's movement and location. According to the Mufti of Wilayah Persekutuan, Dato Seri Dr Zulkifli Mohamad al-Bakri, on the ETS, Muslims should attempt to face the qiblah to perform prayers (Rusli, 2018). In the al-Quran, Allah the Almighty said:

"Turn the face in the direction of the sacred Mosque: where you are, turn your faces in that direction." (al-Quran 2:144)

Nevertheless, if Muslim passengers are not able to ascertain the precise direction of the qiblah, they should face the direction that is most probably direct to the qiblah. In such a condition, when Muslim passengers are unable to locate the exact qiblah direction to perform the prayer, they should pray in whatever direction the vehicle is heading. However, they need to perform the prayer again or replace it ( $\left.q a d a^{\prime}\right)$ once they have reached their destination.

\section{Ablution}

Ablution or the Arabic term wudhu' must be performed as a prerequisite for prayer and the procedure involves freshwater contact with certain parts of the body in particular steps according to the right sequence (Hamid et al., 2015). In the al-Quran, the importance of ablution is stated by Allah the Almighty as follows:

"O you who have believed, when you rise to (perform) prayer, wash your faces and your forearms to the elbows and wipe over your head and wash your feet to the ankles. And if you are in a state of unclean then purify yourselves. But if you are ill or on a journey or one of you comes from the place of relieving himself or you have contact with women and do not find water, then seek clean earth and wipe over your faces and hands with it. Allah does not intend to make it difficult for you, but He intends to purify you and complete His favour upon you that you may be grateful." (al-Quran 5:6) 
The concept of wudhu' is one of the disciplinary acts that should be adopted by each Muslim individual to stay hygienically clean whether at a private or public place (Abdul Rahim, 2005). Therefore, it is important to provide a well-designed facility for ablution (Mokhtar, 2011), preferably installed near or within the prayer area. The ablution facility should be dedicated and separated between genders. Furthermore, to perform prayers comfortably, a good ablution facility and space are important, because the aspect of cleanliness is emphasized in Islam, especially when someone wants to pray (Hamid et al., 2015).

KTMB has already provided the ablution space in the musolla to ease Muslim passengers to perform ablution, but unfortunately, the musolla is accessible for men and women, meaning that it is not segregated, as shown in the figure 1 above. Thus, KTMB should be more concerned with this issue, and provide comfort and satisfaction for the passengers.

\section{Provide Prayer Rug or Mat}

Prayer rug or mat, known as sajjadah al-solah, is generally used by Muslims to perform their solah (prayer) (Department of Standards Malaysia, n.d.) and/or the acts of prostration done during Islamic prayers (sujud), and is found in every Muslim home and is often a constant travel companion that goes with the worshipper (Rym Ghazal, n.d.). Since daily prayers must be performed on a clean surface, the prayer mat serves this purpose and must always be kept clean.

Nonetheless, providing prayer rug or mat is an additional facility that may provide extra convenience to Muslims in performing prayers. According to Saffinee (2017), al-Imam alShatibi recommends beautifying, improving, and refining additional needs for Muslimfriendly products and services without breaching the ethical-moral standards.

\section{Women's Apparel for Prayer}

A proper apparel is one that covers the aurah i.e. the private parts (Saffinee, 2017). Much like the prayer mat, women's apparel for prayer is also an additional element that assists female Muslim passengers in performing prayers. Prayers still can be performed without women's apparel for prayer with certain conditions that should fulfil the requirement of covering the aurah (Mustafa, Tasir \& Jusoh, 2018). In fact, the female parts that need to be covered are the entire body except for the face and the wrists to the fingertips.

\section{Copy of the al-Quran}

The al-Quran is the religious scripture for the followers of Islam. Based on the MuslimFriendly Hospitality Services-Requirements (MS2610: 2015), a copy of translated al-Quran should be made available upon request by the Muslim guest. Islam encourages Muslims to recite the al-Quran in a pure condition at any place (Battour et al., 2011). Therefore, providing al-Quran on the ETS is a good initiative that can motivate and educate Muslim passengers to ponder (tadabbur) on the meaning of Quranic verses. 


\section{Supplication (Du’a)}

$D u^{\prime} a$ or supplication is a way of communicating with Allah the Almighty, when a Muslim requests for blessing, protection, guidance and mercy, with high expectations and hope (Adua, 2015). Allah said in the al-Quran:

“And your Lord said: Supplicate to Me, I shall answer you” (al-Quran 40:60).

Whenever a Muslim sets out for a journey, Islam encourages the recital of $d u^{\prime} a$ for protection, safe return (Quran Academy, 2017), and blessing from Allah (Zulkifli, 2017). Hence, the ETS can provide $d u$ 'a recitation guidance on LCD monitors as a reminder for the passengers.

\section{Gender Segregation for Facilities}

Gender segregation will provide extra comfort for Muslim passengers, especially for women. The segregated facilities for women would have an impact on Muslim tourists' choices (Cetin, 2018). Besides, it is also a religious obligation to prohibit gender integration as to prevent the cause of "fitnah" i.e. temptations or trials which imply evil consequences of lust or aroused desires, indecent acts and false practices (Battour, Ismail \& Battor, 2010). Islam prohibits people from committing sins, such as zina (adultery/fornication), which is considered a major sin and one of the paths to evil (Karamah, 2011). Thus, anything that can lead to zina is prohibited, as stated in the al-Quran:

\section{"Nor come nigh to adultery: for it is a shameful (deed) and an evil, opening the} road (to other evils)." (al-Quran 17:32)

Therefore, gender segregation on the ETS is one way to prevent zina. KTMB can segregate passengers according to gender, as has already been implemented on KTM Komuter in the form of the "female coach only" (Arbee, 2015). KTMB can upgrade the ETS coach into female, male, and family, in order to separate them. The system of purchasing tickets needs to take note of the status and gender of the passengers to provide seats according to gender and other preferences.

\section{Appropriate Entertainment}

In general, the aim of entertainment is to refresh the soul, relieve tiredness, and minimize boredom (Saffinee, 2017). Entertainment is a broad concept and the preferable forms of entertainment on the ETS are watching television, reading, and listening to the audio, all of which are categorized as passive entertainment forms which do not involve movement (Daud, 2018). Hence, providing the appropriate entertainment on the ETS could contribute to the feelings of happiness and relaxation during a trip. Any entertainment must be strictly supervised to ensure it is Shariah-compliant. Therefore, KTMB can identify and provide general non-sensitive entertainment that should suit all kinds of passengers from children to adults, of any race, or religious background. Certain types of entertainment must be avoided, especially those that promote unlawful transgressions such as the exposure of female aurah or private parts, as mentioned in the al-Quran: 
"And tell believing women to reduce (some) of their vision and guard their private parts and not expose their adornment except that which (necessarily) appears thereof...." (al-Quran 24: 31)

Overall, these MFRS elements can be arranged according to the level of necessity, as shown in the figure below.

\author{
Embellishment: \\ -Dua' /Supplication \\ -Appropriate Entertainment \\ Complimentary: \\ -Segregation of gender \\ -Prayer mat \\ -Copy of Al-Quran \\ -Female prayer garment \\ Necessity: \\ -Halal foods and beverages \\ -Prayer facilities including musolla, qiblat direction, \\ prayer time and ablution place
}

Figure 2. The MFRS elements according to the level of necessity

This section can be divided up into subheadings. This will provide a detailed and concise description of the experimental observations, their interpretation and the experimental conclusions which can be drawn.

\title{
4. Discussion
}

\section{Challenges of the MFRS}

MFRS is still a new concept to be implemented in Malaysian Railways. There are many challenges or difficulties, such as the high cost for implementation. In order to achieve Muslim-friendly services, several aspects could surely be changed or upgraded. For example, gender segregation requires high cost, as supported by COMCEC (2017), which mentioned that upgrading existing facilities to become Muslim-friendly is a challenge in the implementation. In the context of MFRS, to provide musolla and ablution facilities that segregate men from women might consume more space and might also affect the number of seats. Therefore, to convert from the conventional to a Muslim-friendly service could reduce revenue and consume a lot of money. However, this challenge can be overcome with well- 
managed operations as providing effective facilities can ease tourists and will also make Malaysia as a top destination choice (Abdul Rahman, 2018).

Another challenge that the MFRS might encounter is the negative perception among non-Muslim passengers of the ETS, since such a service might not fulfil their taste or demand and might cause dissatisfaction. This could lead to a biased perception toward the service, and worst, toward Islam, fuelling Islamophobia i.e. hatred, negative stereotype, and prejudice toward Islam and Muslims (Tiung et al., 2018). Some non-Muslim travellers may prefer alcoholic beverages as their norm and leisure without restriction. As mentioned by Fletcher and Spracklen (2014), alcohol is permissible by law and tradition and is a part of popular culture. As such, non-Muslim passengers might not be satisfied with the ETS service and might refuse to choose the MFRS for travelling.

Moreover, the acceptance and implementation of the MFRS in Malaysia might be complicated because the ETS is managed by the government sector compared to other hospitality services offered by the private sector, where Muslim-friendly services can be implemented with little controversy. Since there is no competition with other companies in the long-distance train service, it is not compulsory for the government to enforce the MFRS as a new standard, which may either be accepted or rejected. Meanwhile, private sector companies have been competing with each other to offer the best services to attract more customers; the Muslim-friendly standard is one of the services being offered. They are willing to convert from the conventional service to a Muslim-friendly service (COMCEC, 2017) to attract more Muslim tourists.

\section{Conclusions}

The Muslim-Friendly Railway Services is introduced to accommodate Muslim travelers' basic needs, which are halal food and prayer facilities. These are the core purposes of the MFRS, although other elements are categorized as additional benefits that can provide comfort to Muslim travelers. According to COMCEC (2017), Muslim-friendly policy preserves the integrity of tourism products and services through the application of the standard and enhances Muslim customers' satisfaction by meeting their needs and requirements.

However, establishing the MFRS involves challenges such as high cost of implementation and the perception of non-Muslims in terms of accepting the implementation. Since this study is still new and has limited resources, a further in-depth research is required to seek for solutions that can overcome the obstacles. Furthermore, more studies should explore the logistics and supply chain in the KTMB cargo service because it is a more familiar area to be scrutinized (Azmin \& Zailani, 2017).

Conflicts of Interest: The authors declare no conflict of interest.

\section{References}

Abdullah, C. Z. H., \& Mustafa, N. A. (2018). Halal information among Muslim travelers and tourist-driven industry. International Journal of Academic Research in Progressive Education and Development, 7(3), 178-186.

Abdul Rahim, A. (2005). A concept of clean toilet from the Islamic perspective. Journal of Islamic Built Environment, 1(1), $71-84$.

Abdul Rahman, H. (2018). Potensi dan Cabaran dalam memajukan pelancongan Islam di Malaysia. Jurnal Sultan Alauddin 
Sulaiman Shah, 506-518.

Adua, S. S. (2015). The relevance of Du'a (supplication) as a weapon to national security. European Journal of Research and Reflection in Arts and Humanities, 3(3), 60-69. Retrieved from http://www.idpublications.org/

Ahmat, N. H. C., Ridzuan, A. H. A., Din, N., et al. (2015). Syariah compliant hotel: the concept and practices. Journal of Tourism, Hospitality \& Culinary Arts, 7(2), 52-66.

Al-Qaradhawi, D. Y. (2015). Halal dan Haram dalam Islam. (Dr. Zulkifli Mohamad al-Bakri, Ed.). Pustaka Cahaya Kasturi Sdn Bhd.

Arbee, A. (2015). KTMB wants to be world's first halal-certified train service. New Straits Times.

Azmin, A. A. \& Zailani, S. (2017). Halal logistics: the role of ports, issues and challenges. Advances in Islamic Finance, Marketing and Management. 309-321. Retrieved from https://doi.org/10.1108/978-1-78635-899-820161015

Azza. (2019). Sekumpulan lelaki solat dalam komuter dikecam, rupa-rupanya... Retrieved December 3, 2019, from https://mv3.cari.com.my

Baharuddin, K., Kassim, N. A., Nordin, S. K., et al. (2015). Understanding the halal concept and the importance of information on halal food business needed by potential malaysian entrepreneurs. International Journal of Academic Research in Business and Social Sciences, 5(2), 170-180. https://doi.org/10.6007/IJARBSS/v5-i2/1476

Bahardeen, F. (2014). The 6 key needs of Muslim travelers. Retrieved November 5, 2019, from https://www.linkedin.com/pulse/20140702023424-46694844-the-6-key-need-of-the-muslim-travelers

Battour, M. (2018). Muslim travel behavior in Halal Tourism. Mobilities, Tourism and Travel Behavior-Contexts and Boundaries. doi: 10.5772/intechopen.70370

Battour, M., Ismail, M. N., \& Battor, M. (2011). The impact of destination attributes on Muslim tourist's choice. International Journal of Tourism Research, 13(6), 527-540. doi: 10.1002/jtr.824

Battour, M. M., Ismail, M. N., \& Battor, M. (2010). Toward a Halal Tourism Market. Tourism Analysis, 15(4), 461-470. doi: $10.3727 / 108354210 X 12864727453304$

Cetin, G. (2018). Muslim friendly tourism (MFT): A discussion, (November). https://doi.org/10.26650/jot.2016.2.1.0005

COMCEC. (2017). Muslim friendly tourism: regulating accommodation establishments in the OIC member countries.

COMCEC Coordination Office, (February), 1-113. Retrieved from http://www.mod.gov.tr/Lists/RecentPublications/Attachments/128/Muslim Friendly Tourism (MFT) Regulating Accommodation Establishments in the OIC Member Countries.pdf

Daud, Z. A. (2018). Elements of Muslim friendly entertainment in hotel. International Islamic University Malaysia. Department of Standards Malaysia. (n.d.). MS2610: 2015 Muslim Friendly Hospitality Services—Requirement.

Fletcher, T. \& Spracklen, K (2014) Cricket, drinking and exclusion of British Pakistani Muslims? Ethnic and Racial Studies, 37(8). 1310-1327. doi: 10.1080/01419870.2013.790983

Hamid, A. B. A., Wahab, M. H. A., Alias, A., et al. (2015). Ablution design: the concepts and design criteria. Proceedings of the 2nd International Colloquium of Art and Design Education Research (i-CADER 2015), 487-496. doi: 10.1007/978-981-10-0237-3_48

Hamid, A. B. A., Taib, M. Z. M., Wahab, M. H. A., et al. (2015). The significance of prayer room design standards at shopping complex.

Hariani, D., Rahmanita, M. \& Ingkadijaya, R. (2017). The influence of availability of Muslim friendly facilities towards Indonesian Muslim tourist revisit intention to Japan. TRJ Tourism Research Journal, 1(1), 133-143.

Hashim, N. H., Murphy, J., \& Hashim, N. M. (2007). Islam and online imagery on Malaysian tourist destination websites. Journal of Computer-Mediated Communication,12(3), 1082-1102. doi: 10.1111/j.1083- 
6101.2007.00364.x

Jais, A. S., Aliman, Z. \& Ismail, A. (2017). Muslim friendly practices in the healthcare: current practices and future outlook. doi: $10.13140 / R G \cdot 2 \cdot 2.27348 .81283$

Jais, A. S. (2019). The MS1500:2019 halal food-general requirements (3rd Revision): what's new, what's old, what's next. Halal Note Series-Halal Common).

Kamarudin, L. M., \& Ismail, H. N. (2016). Muslim Tourism: the tendency of Islamic traveling attributes from Malaysia perspective. Proceedings of the International Social Science and Tourism Research Conference.

Karamah. (2011). Zina, rape, and Islamic law: an Islamic legal analysis of the rape laws in Pakistan, 1-15. Retrieved from https://karamah.org/zina-rape-and-islamic-law-an-islamic-legal-analysis-of-the-rape-laws-in-pakistan/

Md Sham, F., Hj Tibek, S. R. \& Jurami, S. K. (2015). Islamic practice among Polytechnic Ungku Omar students. Asian Social Science, 11(24), 39-47. doi: 10.5539/ass.v11n24p39

Mokhtar, A. (2009). Design standards for Muslim prayer facilities within public buildings. Leadership in Architectural Research, Between Academia and the Profession. Retrieved from https://pdfs.semanticscholar.org/fb4f/448dae6f7f2fbd0be7b5054294decfb6a9ea.pdf

Mokhtar, A. (2011). Architectural design standards for Muslim prayer facilities in airport. WIT Transactions on State of the Art in Science and Engineering, 48, 32-138. doi: 10.2495/978-1-84564-570-0/11

Musharraf, M. N. (2016). Shortening and combining of Salah during travel. Australian Journal of Humanities and Islamic Studies Research, 2(1), 53-63.

Mustafa, Z., Tasir, S. F., \& Jusoh, N. A. M. (2018). The concept of Aurah: Islamic dressing code and personel gromming acccording to Fiqh Law. E-Academia Journal, 7(2), 10-19.

Peng, L., Song, X., \& Yang, Y. (2017). Analysis on improving the quality of railway passenger transport service research status at home and abroad, 7-12.

Quantaniah, N. A., Noreina \& Syakinah, N. (2013). Selecting halal food: a comparative study of the Muslim and nonMuslim Malaysian student consumer. 2nd International Conference on Technology Management, Business and Entrepreneurship, 438-453.

Quran Academy. (2017). Travel Dua \& best practices. Retrieved November 5, 2019, from https://quranacademy.io/blog/travel-dua-best-practices/

Razak, M. I., Alias, Z., \& Samad, I. H. (2015). Overview of halal products and services in Malaysia and global market. International Journal of Economics, Commerce and Management, 3(3), 1-9. Retrieved from http://ijecm.co.uk/wp-content/uploads/2015/03/3320.pdf

Rusli, M. F. (2018). Al Kafi \#828: hukum solat dalam keretapi laju, bagaimanakah arah kiblat. Retrieved from https://muftiwp.gov.my/artikel/al-kafi-li-al-fatawi/2637-al-kafi-828-hukum-solat-dalam-keretapi-lajubagaimanakah-arah-kiblat

Rym Ghazal. (n.d.). The significance of prayer mats. Retrieved November 4, 2019, from http://www.thenational.ae/artslifestyle/family/the-significance-of-prayer-mats.

Salleh, N. Z., Nor, R. M., \& Azmin, N. A. (2019). Exploring challenges in providing Muslim friendly tourism services in Northern Japan: A case study in Akita prefecture. Malaysian Journal of Consumer and Family Economics, 22(4), $42-53$.

Saffinee, S. S. (2017). Development of Audit Checklist for Muslim-Friendly Hotel's Room. International Islamic University Malaysia.

Selamat, M. N., \& Zolkiply, H. (2017). Persekitaran kerja dan komitmen pekerja di Keretapi Tanah Melayu Berhad 
(KTMB), Kuala Lumpur. Journal of Social Sciences and Humanity, 14(5). Retrieved from https://pdfs.semanticscholar.org/03fd/fee9514c500f23055a2677376a164c9356da.pdf?_ga=2.264157644.15928885 04.1592463206-1096012878.1592463206

Shakona, M., Backman, K., Backman, S., et al. (2015). Understanding the traveling behavior of Muslims in the United States. International Journal of Culture, Tourism and Hospitality Research, 9(1) 22-35. https://doi.org/10.1108/IJCTHR-05-2014-0036

Tarabishy, M. N. (n.d.). Jurisprudence of Qibla. Retrieved from http://www.icoproject.org/pdf/tarabishyqiblah_2014.pdf

Tiung, L. K., Meri, A., Othman, S. S., et al. (2018). Wacana Islam dalam media Malaysia: obligasi, isu-isu dan cabaran. Jurnal Komunikasi Borneo, 6, 8-20.

Yunus, Y. (2005). Sembahyang Jamak dan Qasar adalah sedekah Allah. Johor, Malaysia: Perniagaan Jahabersa.

Zawawi, M., \& Ramli, N. (2017). "Shari'ah compliant hospitality services" or "Muslim friendly hospitality services": searching for a balance. Malaysian Journal of Consumer Family Economics, 20(1), 28-37. Retrieved from http://irep.iium.edu.my/id/eprint/62460

Zulkifli, M. A. B. (2017). Bayan Linnas siri ke-99: kapal terbang dan kepentingan doa musafir. Retrieved from http://muftiwp.gov.my/ms/artikel/bayan-linnas/771-bayan-linnas-siri-ke-99-kapal-terbang-dan-kepentingan-doamusafir

Copyright (C 2020 by Abdul Halim, S. N. et al. and HH Publisher. This work is licensed under the Creative

Commons Attribution-NonCommercial 4.0 International Licence (CC-BY-NC4.0) 